\title{
Kvinnor och socialt arbete - vid övergången från filantropi till profession
}

\author{
ANNA-KARIN KOLLIND
}

\begin{abstract}
Professionaliseringen av socialt arbete inleddes vid tiden kring det förra sekelskiftet. Artikeln skildrar ett kapitel $i$ denna historia. I blickpunkten står tre kvinnors samfällda aktiviteter $i$ stugrörelsen, på hemgårdarna, vid etableringen av socialt arbete $i$ industrin samt $i$ arbetet med en ny fackutbildning för socialt arbete. Förbindelserna mellan ideella och professionella aktiviteter är påfallande.
\end{abstract}

Kvinnor spelar en framträdande roll i praktiskt socialt arbete och omsorgsarbete. Så har det också varit historiskt. En relativt omfattande forskning har skildrat viktiga insatser från borgerlighetens kvinnor inom välgörenhet och filantropi i 1800-talets samhällen. Detta mönster gällde också för Sverige. Under i synnerhet senare delen av 1800-talet bildades en rad välgörenhetsföreningar av kvinnor där de oavlönade arbetade med socialt arbete. Filantropen blev en kvinna (Jordansson 1992). Särartsideologin var en bakgrund till det påtagligt stora inslaget av kvinnor $\mathrm{i}$ välgörenhetsarbete. Kvinnan ansågs ha moraliska egenskaper som gjorde henne särskilt lämplig för att

Anna-Karin Kollind är lektor och docent i sociologi och arbetar vid Sociologiska institutionen, Göteborgs universitet. genom en personligt inriktad hjälp bidra till att moraliskt fostra hjälpbehövande. Men som många har påpekat gav välgörenhetsarbetet kvinnor i dessa samhällsskikt även möjligheter att vidga gränserna för sina handlingssfärer. Det gällde i synnerhet gifta kvinnor som var utestängda från yrkesverksamhet. Genom föreningsaktiviteter fick kvinnor möjligheter att vara verksamma $i$ en offentlighet och de öppnade samtidigt upp för nya former av offentliga aktiviteter.

Denna artikel belyser några av de kvinnor som vid 1900-talets början verkade för det sociala arbetets professionalisering. Professionsbegreppet kan ha flera innebörder. Här syftar jag på övergången från social verksamhet som ett väsentligen oavlönat, filantropiskt företag till ett avlönat yrke 
med fackutbildning som grund. Det sociala arbetets förändring från frivilligt filantropiskt arbete till yrkesverksamhet äger rum under 1900-talets första decennier.

Tre kvinnor står här i fokus: Kerstin Hesselgren, Emilia Fogelklou och Herta Svenson. De kände varandra väl och hade kontakter genom flera decennier i vad vi idag kallar ett socialt nätverk. Deras samverkan utvecklades på flera olika arenor och påverkade inriktningen på praktiskt socialt arbete under 1900-talets första decennier. Kerstin Hesselgren är den namnkunnigaste. Hon var på sin tid en framstående socialpolitiker med arbetarskyddsfrågor som främsta specialitet och blev, efter att kvinnorna fått rösträtt, politiskt verksam som riksdagsledamot $i$ många år. Emilia Fogelklou är känd som folkbildare och skribent i religiösa frågor och inte ett namn som primärt förknippas med socialt arbete. Herta Svenson var verksam på Södergårdens hemgård i Stockholm och den första personalkonsulenten i Sverige. Hon är den minst kända, mest bortglömda. Till skillnad från de andra två har hon inte efterlämnat några publicerade skrifter.

Dessa tre kvinnor var mer eller mindre direkt inblandade i en rad projekt kring socialt arbete. Från 1910-talet deltog de i stug- och hemgårdsrörelsen, grundlade socialt arbete i industrin, medverkade i den Kvinnliga medborgarskolan på Fogelstad och tog aktiv del i mentalvårdsrörelsen. Två av kvinnorna var också inblandade $\mathrm{i}$ den nya utbildningen för socialt arbete. Det är dessa olika aktiviteter och sambanden mellan dem som jag vill belysa i artikeln. Syftet är också att visa hur föreställningar om socialt arbete kunde se ut $i$ en tid då detta arbete ännu var en profession i vardande. En annan viktig fråga är betydelsen av kön, speciellt kvinnlighet, i dessa nya verksamheter.

\section{Kvinnliga positioner på 1910-talets sociala verksamhetsfält}

Kring 1910 var alla de tre kvinnorna verksamma i Stockholmstrakten, trots att de vuxit upp i andra delar av Sverige. Kerstin Hesselgren, född 1872, kom från ett brukssamhälle i Gästrikland, Emilia Fogelklou och Herta Svenson, födda 1878 respektive 1886, kom båda från samma småstad i Skåne. Likt många kvinnor med borgerlig bakgrund i denna generation hade de utbildat sig till lärarinnor. Hesselgren och Fogelklou hade kring 1910 lagt om kursen för sina yrkesliv, medan Svensson fortfarande arbetade som lärarinna. Som vi skall se ändrar emellertid även hon sin livsbana de följande åren. Alla tre var engagerade i vad som då ofta benämndes den sociala frågan och som innefattade ett brett spektrum av frågor kring arbetarklassens villkor. Men de tre kvinnornas aktiviteter och kontakter hörde delvis hemma på olika arenor. Hesselgren var verksam i Centralförbundet för socialt arbete (CSA) och Fredrika Bremerförbundet, Fogelklou och Svensson var aktiva i radikala kristna studentgrupper med engagemang $i$ arbetarfrågan. Men vi kommer att se att det mellan dessa olika fält fanns förbindelselänkar.

1910 var Hesselgren sedan något år anställd som skolköksinspektris, en nyinrättad befattning med uppgift att ha tillsyn över den husliga undervisningen i landets 
skolor. Tjänsten anknöt väl till Hesselgrens utbildning som lärarinna i »huslig ekonomi«, alltså skolkökslärarinna, och hon tog itu med att förbättra barnbespisning, skolhygien och att ordna sommarbarnkolonier. Några år tidigare hade hon haft en tjänst som bostadsinspektris och då kommit i daglig kontakt med dåtidens bostadsmisär, fukt och mögel, ohyra och inneboendesystem. Steget bort från lärarinneyrket mot en socialt inriktad yrkesverksamhet hade Hesselgren tagit i början av 1900-talet, då hon rest till London och gått på en utbildning vid Bedford College i „Scientific Instruction in Hygiene». Den tre terminer långa utbildningen till yrkes- och bostadsinspektris var både teoretiskt och praktiskt inriktad. Hon hade läst fysiologi, bakteriologi, kemi, fysik m.m. Någon liknande utbildning fanns inte i Sverige, som då saknade "inspektriser" eller inspektörsuppgifter för kvinnor. Med denna utbildning, som var dyr (Fredrika Bremerförbundet bistod ekonomiskt), fick Hesselgren kompetens att arbeta med "hygienfrågor" som gränsade till det medicinska område hon först hade velat ägna sig åt. Vid denna tid hade ordet hygien en mer vidsträckt betydelse än i dag och innefattade frågor som rörde bostads- och arbetsförhållanden, lämpliga kläder och sund mat. Med denna utbildning i bagaget var det inte konstigt att hon erbjöds tjänsten som bostadsinspektris när den inrättades 1906.

Hesselgren var frisinnat liberal med blick för tidens samhällsfrågor. Centralförbundet för socialt arbete blev under många år en viktig plattform för hennes sociala engagemang. Hon var inte med då förbundet bildades 1903. Det var några av de mer kända kvinnorna inom filantropin i Stockholm, Gerda Meyerson och Gertrud af Klintberg, som tog initiativet till denna sammanslutning av sociala föreningar. Några av de föreningar som blev medlemmar var föreningen Studenter och arbetare, där $\mathrm{G}$. $\mathrm{H}$. von Koch hade varit aktiv, och Föreningen för välfärdens ordnande med Agda Montelius som främsta representant. Flera kvinnoorganisationer var medlemmar i CSA. En av dem var Fredrika Bremerförbundet som representerades av bl.a. Kerstin Hesselgren (Wirén, 1980). Andelen kvinnor i förbundet var som många påpekat stor, kanske inte oväntat eftersom kvinnor dominerade filantropin (Boalt och Bergryd 1974). Förbundets syfte var att samordna det arbete som bedrevs i olika föreningar verksamma med socialt arbete, sprida kunskap om och bidra till att lösa viktiga samhällsfrågor. 1904 publicerade Hesselgren en artikel om tuberkulos i Social Tidskrift, förbundets språkrör, och följande år utredde hon på förbundets uppdrag hur industriarbetet påverkade arbeterskors ekonomiska, sociala och sedliga förhållanden (Hesselgren 1904, 1905). Från 1906 var hon ledamot i förbundets styrelse och deltog de följande åren i en rad utredningar som förbundet initierade liksom i den stora sociala utställningen som öppnades 1906.

Centralförbundet och dess nätverk av kontakter mellan inflytelserika liberala kvinnor och män med engagemang för samhällsfrågor var en väsentlig arena för Hesselgren vid denna tid. En av de frågor förbundet kämpade för var bättre arbetarskydd. En utredning om hemarbeterskornas villkor som Hesselgren och Gerda Meyerson utförde var led $\mathrm{i}$ en sådan kampanj. 
När arbetarskyddet äntligen genom Yrkesfarekommitténs beslut reviderades 1912 blev det också möjligt att inrätta en befattning som yrkesinspektris. Arbetet gällde kvinnodominerade arbetsplatser. Samma år erbjöds Hesselgren tjänsten som inspektris, ett arbete som hon fortsatte med fram till sin pensionering. Inspektrisen skulle enligt förordningen verka för att arbeterskornas kost, bostäder och hälsovård förbättrades. I uppdraget ingick också att höja industriarbetande kvinnor i sedligt och intellektuellt avseende. Hesselgrens yrkesmässiga karriär som inspektris hade helt säkert sin grund både i hennes aktiva arbete i Centralförbundet och i hennes satsning på en engelsk utbildning till ett yrke som då ännu inte fanns i Sverige. Med tidens sätt att se var hon en fackutbildad kvinna som yrkesmässigt var verksam med socialt arbete.

Emilia Fogelklou hade i likhet med Hesselgren försökt ge sitt yrkesliv en annan inriktning än lärarinnans och tagit steget in i Uppsalas akademiska liv. Efter att som privatist ha läst in studentexamen hade hon på ett år tagit en filosofie kandidatexamen och därefter fortsatt med teologiska studier fram till examen 1909. Det akademiska studiefältet hade öppnats för kvinnor redan 1873 med vissa undantag, bland annat för teologi. Fogelklou blev den första svenska kvinna som tog en teologisk examen.

Svenska kyrkan var inne i en svår kris med kraftiga slitningar under trycket av nya samfundsbildningar och starka motsättningar mellan ortodoxa teologer och framstegsvänliga liberalteologer. Under uppsalaåren fick Fogelklou kontakt med flera av dessa liberaler, såsom Nathan Söderblom och Manfred Björkquist, vilka fick stort inflytande även på henne. I Uppsala bildades den s.k. korstågsrörelsen, kristna studenter som ville samverka med arbetarna och verka för en inre mission, så att hela folket skulle "genomsyras av evangelium». Att öppna en kristen folkhögskola i Hampnäs var ett led i missionsarbetet. Fogelklou var djupt engagerad i dessa aktiviteter. Meijling Bäckman skriver: „I alla dessa ungkyrkliga sammanhang finner vi Emilia Fogelklou. Hon är Söderbloms elev och gäst på Stabby, hon talar vid Huskvarnamötet 1907, hon är/--/ kamrat med Manfred Björkquist. Hon deltar i planerna på Hampnäs folkhögskola och hon skriver i Vår Lösen. Men hon blir inte korstågsfarare» (Meijling Bäckman, 1997, s 25).

Fogelklou var starkt intresserad av tidens sociala fråga och »hade länge drömt om att finna en uppgift där hon kunde förena sin kristna tro med en aktiv social insats» (ibid. s 28). Hösten 1910 och våren 1911 fick hon tillfälle att närmare studera vad som skedde i Europa bland kristna socialt radikala grupper. Tack vare ett resestipendium kunde hon bland annat besöka settlementrörelsen i London och de s.k. sillonisterna i Frankrike, en dåtida variant av dagens befrielseteologi.

Det är osäkert om Fogelklou med sina högre studier hade avsett en annan yrkesverksamhet än lärarinnans. Hon ville studera vidare men hade inte ekonomiska möjligheter till det. Under studietiden publicerade hon en del artiklar och även en bok, och det är möjligt att det var ett framtida skriftställarskap hon hade i tankarna. Men 1911 var hon tillbaka i tjänst som lärare, denna gång vid Djursholms Samskola. Där träffade hon och Herta Svenson varandra. 
Herta Svenson kom till Djursholm som guvernant för Nathanael och Elsa Beskows barn, men blev sedan lärarinna vid Samskolan. Teologen Nathanael Beskow var skolans rektor och en känd gestalt bland de radikala liberaler som vid denna tid bosatte sig i Djursholm. Flera i kretsen kring Centralförbundet, såsom G. H. von Koch och Gerda Meyerson, bodde i Djursholm och umgicks med familjen Beskow. Koch betydde t.ex. mycket för Nathanael Beskows utveckling. Beskow var en oortodox teolog som av samvetsskäl hade avstått från att prästvigas, men tack vare den radikala borgerlighet som då bodde $i$ Djursholm fick han ett kapell byggt till sig. Han var en av det fåtal teologer som engagerade sig för arbetarfrågan och ansåg att socialism och gudlöshet inte behövde sammanfalla. I samband med storstrejken 1909 gav han i ett offentligt tal arbetsgivarsidan skulden för konflikten och hävdade att det måste »skapas en vilja till samförstånd och samarbete». För att sprida en sådan vilja måste klasshatet bekämpas, inte minst i överklassen (Beskow 1910). Beskow var övertygad om att ett demokratiskt samhälle på sikt skulle växa fram med inflytande för arbetarna, men han var i likhet med många andra aktivt kristna orolig för att de skulle överge kristendomen. I hans perspektiv behövde arbetarrörelsen kristendomen. Men lika uppenbart var att kristendomen behövde arbetarrörelsen (Olson 1982, Sjöholm 1972).

Beskow skrev i Social Tidskrift och hade kontakter med många av dem som var aktiva i Centralförbundet. En av dem var Ebba Pauli som medverkade i dess utredning om fattigvårdsfrågan. Kring 1910-11 diskuterade hon och Nathanael Beskow livligt om att etablera ett settlement i Sverige. Beskow hade vid ett studiebesök i London i slutet av 1890-talet kommit i kontakt med flera settlements, bland annat Toynbee Hall, en förebild för denna rörelse, där kristna bildade grupper bosatte sig i slumområden. Även Hesselgren hade besökt detta berömda settlement under studietiden i London, liksom Fogelklou på sin studieresa. Genom att bilda ett settlement ville man i praktisk handling visa att kristendomen kunde vara en positiv kraft även i arbetarnas liv. Man ville »bygga en bro över den klyfta som skiljer människor åt, vilka anses höra till olika samhällsklasser». Här gällde det att träffas "människa mot människa», inte som representanter för olika klasser (Olson 1982 s 59). Flera kvinnliga lärare och studentskor var med i den förberedande planeringen till det som 1912 blev Sveriges första hemgård, som settlementen kom att kallas här. Vi vet att Fogelklou och Herta Svenson hörde till de aktiva inom denna grupp (Sjöholm 1979).

Vi ser alltså att Hesselgren, Fogelklou och Svenson kring 1910-11 var aktiva på två delvis skilda men betydelsefulla arenor för verksamheter som var ägnade åt dåtidens sociala fråga. 1911 tog Herta Svenson initiativ till ett kristet inspirerat socialt arbete bland arbeterskor. Det blev en betydelsefull mötespunkt för dessa tre kvinnor.

\section{Kristna kvinnliga aktivister: Stugrörelsen och semesterhem för arbeterskor}

Våren 1911 spreds ett upprop till industriarbeterskor, där det bland annat stod 
att läsa: „Vi kvinnliga studerande från Uppsala och Stockholm, ha känt ett behov av att komma i beröring med unga kvinnor från annat arbetsområde än vårt eget för att under några dagar mötas utanför klasskampens råmärken såsom människor blott.» Det framgick att deltagarna under dessa dagar av gemenskap även skulle tala om "några av livets stora och djupa frågor", till vilka hörde "frågan om Jesus Kristus." Samtalet skulle dock föras "utan strid om åsikter ", så att var och en kunde »komma utan fruktan för tryck av något slag «. ${ }^{1}$

Åtta kvinnor hade undertecknat denna skrivelse. En av dem var Herta Svenson och flera av de övriga var nära vänner till Emilia Fogelklou. Förutom kontakterna mellan olika grupper från skilda samhällskikt och de andliga samtalen var tanken att dessa möten också skulle leda fram till socialt arbete. Man planerade att ordna stugor som kunde bli sommarkolonier för arbetarbarn.

Mötet hölls i juni 1911 »i en vacker och inbjudande natur", då initiativtagarna trodde att det skulle vara lättare att lära känna varandra i en sådan miljö. 22 arbeterskor kom och Fogelklou var en av föreläsarna. Redan vid första mötet blev de kvinnliga akademikerna medvetna om att arbeterskorna hade stort behov av vila

1 Tobaksarbeterskor, Kvinnohistoriska samlingarna, Göteborgs Universitetsbibliotek (KHS, UB, GU) B 9, kartong 83. Olson (1982) s 77-80 liksom Eskilsson 1991, s 135 f har beskrivit stugrörelsen och hemgårdarna. Bland dem som undertecknade den första kallelsen 1911 fanns även Jeanna Oterdahl; Dagny Thorvall; Ingeborg Wikander; samt Andrea AndréenSvedberg, senare betydelsefull på Kvinnliga medborgarskolan på Fogelstad. och rekreation. Stugan planerad till barnkoloni kom därför att i stället användas för arbeterskors rekreationsbehov. ${ }^{2}$ En viktig uppgift blev därefter att ordna sommarstugor runt om i landet i en vacker omgivning. De kvinnliga aktivisterna kallade sig ganska snart för stugrörelsen, en till att börja med relativt informell gruppering som snart spreds utanför Stockholmstrakten och efterhand tillsattes kommittéer i många andra städer. Stugrörelsens överordnade tankegång var att gemenskapen i stugorna skulle kunna överbrygga klasskillnaderna. „På stugorna bli alla lika, medlemmar av den stora stugfamiljen. Syskon till varandra och till alla, alla människor", skrev Herta Svenson (Svenson, 1916).

Följande år fortsatte på samma sätt med några dagars sommarmöten där arbeterskor och "studentskor" samlades på någon naturskön plats och ägnade sig åt föredrag och samkväm. Samtidigt arbetade rörelsens aktivister praktiskt med att förvärva stugor, utrusta och ställa dem i ordning för att ge möjlighet till rekreation under sommaren. 1915 hölls ett möte i Södertuna. Kerstin Hesselgen deltog i planeringen och på själva mötet föreläste både hon och Fogelklou. Möjligen var det nu de tre kvinnorna kom i kontakt med varandra första gången, men det är också möjligt att de hade träffats redan tidigare. Också på följande års möte med representanter från större städer i hela landet deltog alla tre.

2 Historik beskriven i ansökan från Hagvikskommittén för Stockholms stugförening om pengar från Stiftelsen Lars Hiertas Minne år 1924. Tobaksarbeterskorna, KHS, UB, GU B9, kartong 83 . 
Dessa sommarmöten fortsatte varje år under 1920- och 30-talet som ett led i försöken att ge arbeterskor möjligheter till en semestervistelse på landet. Detta var tveklöst också ett av de många sätt på vilket socialt arbete kunde bedrivas vid denna tid. Genom donationer av hus och andra gåvor lyckades man få tillgång till ett relativt stort antal stugor och förse dem med nödvändig utrustning. Med många timmars ideellt arbete och engagemang lyckades man också hålla verksamheten i gång under många år.

Personer knutna till Centralförbundet för socialt arbete med särskilt engagemang i arbeterskors villkor intresserade sig naturligtvis även för dessa kvinnliga akademikers aktiviteter. Kerstin Hesselgren var förvisso intresserad. Som yrkesinspektris skulle hon granska arbeterskors arbetsförhållanden och främja deras kostförhållanden, bostäder och sedlighet. I sitt arbete fick hon uppleva att svårigheterna att förändra inte alltid enbart berodde på arbetsgivarna. Arbeterskor kunde ibland ställa sig mycket oförstående och misstänksamma till hennes krav på bättre förhållanden i fabrikerna, såsom toaletter och rinnande vatten. Det skulle dröja flera år innan hon, denna representant för staten och borgerligheten, lyckades vinna arbeterskornas förtroende (HamrinThorell m.fl. 1986; Gustafsson 1989; Lindblad 2002). Stugrörelsen gav Hesselgren en inkörsport till det slags mer personliga kontakter med arbeterskor som hon hade saknat, kontakter av ett slag hennes tjänst som inspektris inte underlättade.

En annan kvinna starkt engagerad $i$ arbeterskornas sak var Gerda Meyerson, en av initiativtagarna till CSA. Även hon blev en flitig gäst på stugfolkets möten, åtminstone efter 1915. Meyerson hade utbildat sig till yrkesinspektris i Danmark för att bättre kunna gagna arbeterskornas sak. ${ }^{3}$ Sedan 1904 hade hon drivit Föreningen hem för arbeterskor, och hon hade även ett sommarhem i närheten av Stockholm där arbeterskor kunde få återhämta sig. Liksom CSA var hon angelägen om att arbetare skulle få betald semester. I sin bok Arbeterskornas värld(1917) framhöll Meyerson att stugfolkets sommarstugor inte bara var till för att ge "sommarvila på landet", utan också för att »driva fram semesterfrågan" (s 146).

Stugrörelsens möten mellan studentskor och arbeterskor kan ses som en parallell till den manliga sammanslutningen, Studenter och arbetare, men också till den tidigare nämnda korstågsrörelsen bland kristna manliga studenter. Här fanns en tydlig vilja till kontakt över klassgränser men också viljan till en kristen gemenskap. Liksom Beskow och Pauli kände de kvinnliga aktivisterna en oro över sekulariseringen. Men de ville också förnya, bryta upp stelnade former i den kristna kyrkan och göra något praktiskt som förbättrade arbeterskornas villkor. Kombinationen av andlig och praktisk verksamhet utgjorde en central del i det sociala arbete stugrörelsen bedrev. Dessa inslag fanns också i andra filantropiska projekt, där folkuppfostran och praktisk hjälp förenades. Ett exempel är Södra kristliga föreningen af unga kvinnor

3 När Hesselgren tillfrågades om hon ville bli yrkesinspektör föreslog hon själv Meyerson i stället, eftersom hon hade mycket längre erfarenheter av arbeterskornas villkor. Enligt Hesselgren ansågs den 6 år äldre Meyerson vara för gammal. 
(KFUK) som hade bildats redan 1887 och som med samma målsättning som stugrörelsen verkade bland arbeterskor. Utifrån tanken att moralisk daning var meningslös utan praktisk kunskap anordnade föreningen kurser, föreläsningar, utbildningar, inackorderingshem och även sommarstugor för rekreation (Norlander, 1995). Denna kombination av praktiskt och andligt var också framträdande i den verksamhet som kom att känneteckna Birkagården, den första hemgården. Det finns flera beröringspunkter mellan Birkagården och stugrörelsen, inte minst när det gäller de personliga anknytningarna.

\section{Den första hemgården}

Settlementrörelsen ville visa gudstankens innebörd genom praktiska verksamheter i slumområden. En oortodox religiös anda inspirerade dem som där skulle skapa mötesplatser, förmedla bildning och överbrygga klassmotsättningar. Där bedrevs ett slags missionsarbete på hemmaplan. "Genom settlementen kom slumkvarteren att koloniseras av folk ur de högre och bildade klasserna"(Olson 1982, s 42).

I Sverige etablerade som tidigare nämnts Ebba Pauli och Nathanael Beskow 1912 det första settlementet, Birkagården, i Stockholm. I deras förberedande diskussioner deltog även flera av de unga kvinnor som startade stugrörelsen. Dagny Thorvall, en av initiativtagarna till det första stugmötet 1911, arbetade och bodde på Birkagården under många år. Medicine kandidaten Märta André, som senare blev föreståndare för Socialpolitiska institutet och ansvarig för dess praktiska kurs, hörde till de tidiga i stugrörelsen och arbetade på Birkagården de första åren. Så gjorde också Herta Svenson. Emilia Fogelklou tycks ha varit en betydelsefull aktör i planeringssamtalen och blev så småningom lärare på Birkagården (Sjöholm 1972, s 244, 356).

Enligt ett tidigt dokument skulle Birkagården »bereda människor från olika arbetsområden och samhällslager tillfälle att mötas som likar och dela med sig åt varandra av sin livserfarenhet» (cit. i Sjöholm, 1972 s 243). Verksamheten omfattade både barn, ungdomar och vuxna. Man ordnade kindergarten, söndagsskolor, sommarkolonier, lek- och arbetsstugor, pojk- och flickklubbar. Där fanns bibliotek, studiecirklar och hemaftnar för mödrar. Ofta anordnades också föredragsaftnar.

1916 öppnades en folkhögskola på Birkagården som påföljande år drevs i samarbete med $\mathrm{ABF}$ och hade Gillis Hammar som rektor. Det var den första folkhögskola som vände sig till arbetare och den första som var placerad i stadsmiljö. Fogelklou kom dit som lärare under två års tid. Alla andra lärare höll i början lektioner gratis, men hon anställdes "för att ge 'en viss stil' åt verksamheten", som Hammar senare uttryckte det (cit. av Olson 1982, s 74). Likt flera andra lärare bosatte hon sig på Birkagården. Arbetet på folkhögskolan upplevde hon som en nystart i livet (Fogelklou 1979, s 31f).

I ett brev beskrev Fogelklou 1916 sina erfarenheter: "Birkagården har öppnat en folkhögskolekurs för arbetslösa, mest säsongarbetare, särskilt målare. Anmälan om kursen har anslagits i fackföreningarna. Ett härligt material har kommit, varav två ungsocialister och resten ungdemokrater. Jag har haft religionshistoria med dem, 
en koncentrerad kurs på 1 à 2 och t.o.m. 3 timmar per dag (det sista genom diskussion). Ett kunskapshungrigare auditorium har jag aldrig skådat. Själva Brand har talat vänligt om kurserna, du vet hur de eljest fruktar allt 'i sällskap med Jesus', som ju för dem fått betydelse ej av en levande person - utan av en skylt för samhällelig efterblivenhet i kyrkans namn.«( Fogelklou 1979, s 31f).

Ett annat brev, denna gång till Klara Johansson, skildrade samverkan mellan Birkagården och A.B.F.: "Jag har verkligen varit med om invigning av en ny trafikled dessa dagar. Du skulle sett alla dessa från 108 föreningar, verkstadsklubbar etc. utskickade människor i 20-25 års ålder, som under två dagar samlades i Birkagården. En hel del av Brands och Politikens medarbetare bl.a. Och de hade sett Birkagårdens redogörelse - som flera av oss förut tyckt onödigt demonstrativ med altare och kors utanpå - och ändå kom de, och ur alla talande brusade en ström: 'vi behöver någon slags kultur för hjärta och känsla såväl som för intellektet.' - En trevande fråga som det är förödmjukande att stå inför och förväntas kunna svara på." Vad som kunde komma ut av samverkan var oklart, men i Fogelklous ögon hade det öppnats en förbindelse mellan två olikartade rörelser som uppstått walldeles samtidigt, ovetande om varandra. Och nu har de trevat sig fram till ett handslag." (Fogelklou 1979, s 182)

Flera av de akademiska kvinnor som tidigt deltog i stugrörelsen var också aktiva med att starta och driva nya hemgårdar. Ingeborg Wikander och Märta André var båda med om att öppna Nordgården, den första hemgården i Göteborg. Agda Hedvall, en annan av väninnorna, blev först aktiv på Birkagården och därefter föreståndare vid Södergården, den andra hemgården i Stockholm. Det var Herta Svenson som tog initiativet till Stockholms andra hemgård.

Arbetet i stugrörelsen och på Birkagården påverkade Svensons yrkesbana, hennes övergång från ett arbete som lärarinna till socialt arbete i industrin. För denna nya yrkesinriktning spelade Kerstin Hesselgren en viktig roll.

\section{Socialt arbete $\mathrm{i}$ industrin blir ett yrke}

Genom arbetet som yrkesinspektris och bland annat kontakterna med stugrörelsen och Birkagården kom Hesselgren i närmare beröring med fabriksarbeterskornas värld. Hon deltog i och ledde flera hjälpprojekt mot arbetslösheten vid krigsutbrottet 1914. Vid en sådan jordbrukskoloni 1917 deltog även Fogelklou (Fogelklou 1954, s 89). Bland arbeterskor mötte Hesselgren familjer med dåliga kostvanor och lade märke till bristande kunskaper om matlagning, hushåll och ekonomi. Det behövdes, menade hon, någon form av socialt arbete inom industrin. I England hade hon under sin utbildning mött fenomenet "social secretaries", kvinnor som på större fabriker tog sig an arbetares problem. I Sverige kallades de efter tysk förebild "fabrikssystrar« och fanns sedan 1910 på några större företag. Sådan hjälpverksamhet var i ibland inordnad i de intressekontor som gav arbetare hjälp i ekonomiska frågor. Fabrikssystrar bedrev en form av frivilligt socialt arbete utan ersättning. På Sandvikens bruk arbetade till exempel bruksägarens dotter 
som oavlönad fabrikssyster (Gustafsson, 1989).

Hesselgren ville professionalisera socialt arbete och det gällde även detta område. Hon lyckades övertyga chefen för Tobaksmonopolet om behovet av en fabrikssyster och 1915 anställdes Herta Svenson för denna uppgift. Hennes skildring av sin bakgrund illustrerar en möjlig utbildningsgång för en dåtida socialarbetare. Den visar även att det var Hesselgren som föreslog henne: "Min lärarinneutbildning blev kompletterad genom en kortare sjukvårdskurs vid Ersta Diakonissanstalt och tre månaders arbete som tobaksarbeterska. Även min tidigare erfarenhet av kontakt med industrins problem, då jag under mina ferier varit på sommarstugorna, kunde anses som någon form av förberedelse, som gjorde att Hesselgren vågade detta experiment. Jag kom ej att gå igenom den 1åriga kurs för socialarbetare, som denna tid ordnades av Centralförbundet för socialt arbete, en kurs som flera av mina kolleger gått igenom. u $^{4}$

1921 ändrades titeln från fabrikssyster till personalkonsulent. Vad gjorde då Svenson de första åren? Hur utformade hon arbetet? Enligt en verksamhetsrapport för 1916 hade det bestått i att ısöka befordra hygien och trevnad i fabrikslokalerna"; "ha uppsikt över folkköket, göra inköp för dess räkning samt räkna och omhändertaga dess dagskassau; "göra ronder i arbetssalarna /.../ för att bereda möjlighet för personalen att utan att lämna sitt arbete kunna göra behövliga rådfrågningar». Hon gjorde

4 Herta Svenson om sig själv, odaterat, i Tobaksarbeterskorna, B 9 kartong 107. hembesök hos frånvarande eller sjuka, hjälpte dem som behövde komma till sjukhus eller få andra råd, anmälde olycksfall, samarbetade med sociala inrättningar och förmedlade lån via intressekontoret. Hon startade även en koloniträdgård, ordnade barnkoloni, matlagningskurser och olika slags kvällskurser. ${ }^{5}$

Gerda Meyerson har betydligt mer målande än verksamhetsberättelsens lite torra ton skildrat allt vad denna fabrikssyster tog sig för. Hon beskriver hur matsalen fick en hemlik karaktär. Förutom att hållas "skinande ren" pryddes den av vaser "med grönt och blommor" och på väggarna sattes upp "vackra tavlor». Meyerson berättar om en koloni som fabrikssystern ordnade för arbeterskornas barn redan den första sommaren och kurser i matlagning och språk. I ett litet mottagningsrum tog fabrikssystern hand om mindre skador. Hos henne kunde man finna "förståelse och sympati« och någon att anförtro "sina bekymmer" (Meyerson, 1917, s 76-80).

En del aktiviteter hängde samman med den hemgård som växte fram ur Svenssons arbete vid Tobaksmonopolet. Hon upplevde att de anställda behövde en plats som underlättade en "god användning av fritiden". Genom bolaget lyckades hon få tillgång till en våning, som Stockholms Stugfolk gjorde i ordning till en hemtrevligt inredd lokal. ${ }^{6}$ Den togs i bruk 1916 som Södergårdens hemgård. Allt fick ske med

5 Redogörelse för år 1916 av H. Svenson f o $\mathrm{m} 27 /$ 4 1916, Tobaksarbeterskorna, B 9 kartong 80.

6 Stockholms Stugfolk bildades 1915. Deras uppgift var att genom handarbete och försäljning på basarer skaffa medel till stugorna och verksamheten. 
små medel, då bolaget till att börja med enbart bidrog med hyran. Under de första åren drev Svenson verksamheten på sin fritid utan några anslag. Efterhand övertog dock tobaksbolaget driftskostnaderna, varvid aktiviteterna koncentrerades till dem som arbetade på bolaget. Precis som på Birkagården hade man omväxlande praktiska kurser (till exempel hushållsarbete, sömnad, strykning och hattsömnad) och teoretiska (föreläsningar och språkundervisning). Det fanns klubbar, samkväm, sångkörer och amatörteater (Sundin 1986). Både Hesselgren och Fogelklou hörde till de föreläsare som ofta återkom. Socialt arbete i kombination med folkbildningsarbete var det som kännetecknade de tidiga hemgårdarna.

De följande åren anställdes flera kvinnor som personalkonsulenter på olika håll. För Hesselgren innebar detta viktiga kontaktpersoner med fabriksvärlden. Det var en personalgrupp som ofta befann sig i en isolerad arbetssituation, med ett ibland besvärligt förhållande till verkmästare och andra arbetsbefäl som saknade intresse för arbetarnas sociala situation. I ett försök att bryta denna isolering ordnade Hesselgren 1921 en kurs för personalkonsulenter på Fogelstad. Följande år bildades föreningen SAIA, föreningen för Social-Arbetare inom Industri och Affärsvärld, alltså en yrkessammanslutning. Vid båda tillfällena deltog naturligtvis Svenson men också Fogelklou (Fogelklou 1954, s 90). Kanske var det därför Fogelklou kände sig delaktig, som hon skrev i brev till Hesselgren 2/2 24: "Jag tycker ju liksom att jag hör med på ett litet hörn i SAIA».

Både Hesselgren och Fogelklou hörde till de återkommande talarna på SAIA:s kurser och årsdagar. Hesselgren talade om arbetslivet och dess ledningsfrågor; Fogelklous anförande rörde alltid psykologiska frågor. Korrespondensen mellan dem på 20-talet - och även senare - gällde ofta föreningens angelägenheter. Fogelklou var under många år medlem i denna, trots att hon aldrig arbetade som personalkonsulent.

Hesselgren blev ordförande för SAIA och stod kvar som hedersordförande fram till 1949. Föreningen skulle enligt stadgarna "höja och utveckla det sociala arbetet inom företagen, verka för att socialarbetarna erhålla en grundlig och effektiv utbildning samt bereda egna medlemmar möjlighet att öka och fördjupa sina insikter i vad som rör arbetetu.? Fortbildning och återkommande kurser var viktiga inslag i denna helt kvinnodominerade förenings arbete. Likt Birkagården fick den ekonomiskt stöd från en av de fonder som CSA förvaltade.

1922, samma år som SAIA bildades, hölls den första "urkursen" på Fogelstad, upprinnelsen till det som 1925 blev Kvinnliga medborgarskolan. Hesselgren tillhörde den inre kretsen, Fogelklou fanns med i förtroenderådet som var en referensgrupp och var en regelbunden föreläsare på skolan (Eskilsson 1991, s.159ff; Fogelklou 1954, s. 92). Även Svenson tycks ha varit viktig i sammanhanget, "en av de verkligt betydelsefulla", skriver Isaksson och Linder utan närmare motivering (1980, s 73). Vi kan notera att Honorine Hermelin, skolans rektor, hade

7 Stadgar för SAIA, Kerstin Hesselgrens handlingar, KHS, UB GU, A14, kartong II 58. Vid föreningsstiftandet fanns även Ida Fischer med, yrkesinspektris och en av de tidigt aktiva inom "stugrörelsen". 
varit aktiv i stugrörelsen. Men jag skall här inte gå närmare in på denna medborgarskola, vars främsta syfte var att ge kvinnor vidgade kunskaper för att de skulle kunna använda sin nyförvärvade rösträtt. Man bör dock hålla i minnet att också denna skola hade en klassöverskridande målsättning, och många av de arbeterskor som gick på folkhögskolan rekryterades från hemgårdarna (Eskilsson 1991, s 138).

Med utgångspunkt i yrkesinspektrisens och fabrikssystrarnas arbetsuppgifter, i nära anslutning till den ideellt arbetande stugrörelsen och erfarenheterna från hemgårdarna, hade ett nytt yrke vuxit fram, ett avlönat arbetsfält väsentligen avsett för kvinnor. Det var ett yrke som definierades som socialt arbete, med den vida innebörd detta begrepp hade i början av 1900-talet. Parallellt med de olika samverkande processer vi här har kunnat följa hade CSA tagit initiativ till utbildning i socialt arbete. Också i de uppgifterna var Hesselgren aktiv.

\section{Utbildning för socialt arbete}

En diskussionsfråga när Centralförbundet bildades var utbildningsbehov för dem som ville ägna sig åt socialt arbete. Möjligheterna var begränsade. Utbildning till diakon eller diakonissa var en möjlig väg (Boalt \& Bergryd 1974, s 12). Vissa filantropiska organisationer såsom Föreningen för välfärdens ordnande arrangerade kurser och utarbetade anvisningar för socialt vårdararbete (Qvarsell 1993). Det stod ändå alltmer klart att detta arbete höll på att förändras och ställde nya krav på fackkunskaper. I CSA:s minnesskrift från 1928 hävdades att socialt arbete inte längre var en tillfällig verksamhet för kvinnor, utan på väg att bli ett »kall, ett yrke, vilket liksom alla yrken krävde sin fackmässiga utbildning" (Fjällbäck Holmgren, 1928, s 31 f).

I den kommitté som tillsattes för att utarbeta en lämplig kurs ingick Hesselgren. Den första kursen 1910 leddes av henne. Den var tänkt för dem som »skulle ägna sig åt bostads- och hemarbetsinspektion, barnavårdsinspektion, arbetsförmedling, socialt arbete vid fabriker, vice värdskap i hus för mindre bemedlade, o.s.v.» (Fjällbäck Holmgren, 1925, s 424). Dessa tänkta målgrupper ger samtidigt en inblick i vad som vid denna tid kunde avses med socialt arbete. Kursen innehöll både teoretiska ämnen och praktiska moment. Hesselgren ledde även de tre följande kurserna och föreläste i hygien. De första kurserna var endast på en termin, vilket befanns vara alltför kort. Kursen utökades därför till två terminer och sedan till tre. I början stod kurserna öppna för både män och kvinnor, senare enbart för kvinnor med längre skolutbildning. Någon motivering till denna förändring framgår inte (Fjällbäck Holmgren, 1925, 1928).

Hesselgren fortsatte i flera år att undervisa i socialhygien efter det att verksamheten hade vidgats genom att Institutet för socialpolitisk och kommunal utbildning och forskning startade i Stockholm 1921. Vid sidan av ämnen som nationalekonomi, statskunskap, socialpolitik och kommunal förvaltning undervisades även i psykologi och etik. De första åren hade en läkare, David Lund, ansvaret för undervisningen i psykologi. Mellan 1923 och 1929 var Fogelklou examinator i psykologiämnet. 
Något tidigare hade Fogelklou sagt upp sig från en lärartjänst på folkskoleseminariet i Kalmar för att äntligen kunna ägna sig åt studier och skriftställarskap. Det innebar att hon stod utan fast inkomst. Föreläsningarna på socialpolitiska institutet var relativt få men försörjningsbidraget välkommet. Fogelklou var eftertraktad som föreläsare, men erbjudandet att föreläsa på institutet var långt ifrån självklart. Mycket talar för att Hesselgren rekommenderade henne. Deras brevväxling på 1920-talet är starkt fokuserad på denna undervisning. Fogelklou diskuterade timantal, kursuppläggning etc. med Hesselgren, som också ibland fick vara kontaktperson med institutet för hennes räkning.

Ulla Pettersson hävdar att socialpolitiska institutets utbildning främst inriktades på tjänstemän i kommunal förvaltning och var dåligt anpassad till socialarbetares praktiska arbetsuppgifter. Den begränsade psykologiundervisningen handlade sällan om mänskliga relationer (Pettersson 2001, s 126, 195). Då Fogelklou började föreläsa hade hon flera års arbete på Birkagården bakom sig, men inte som Hesselgren eller Svenson direkta erfarenheter av socialt arbete. Hennes föreläsningsämne fanns inte som akademisk disciplin och den dominerande psykologin var antingen experimentell eller medicinsk. Undervisningen på institutet gav Fogelklou möjlighet att utveckla den typ av psykologi som intresserade henne mest, en som handlade om mänskliga relationer

De första terminerna höll Fogelklou enbart ett tiotal föreläsningar. Men de tycks ändå ha betytt något särskilt för henne, sannolikt därför att hon upplevde undervis- ningen som banbrytande. Det framkommer i ett brev till Hesselgren, tillsammans med besvikelse över att antalet timmar hade reducerats. „Uppgiften intresserar mig som du förstår på det allra högsta, men du ser också huru möjligheterna blivit reducerade för banbrytarearbete.» Färre timmar gjorde det omöjligt att genomföra vad hon trott att det skulle röra sig om: »en grundligare kurs, med den allmänna psykologin som inledning och sedan 'människokunskap', anpassad efter de olika sociala områden åhörarna kunde tänkas gå in påı. ${ }^{8}$ Alltså en betydligt mer praktiskt orienterad kurs.

Slitsamma kurser kunde få Fogelklou att känna sig som en dilettant. »Det är en klen tröst, att vägen är så pass litet uppbruten, att även andra skulle känna sig som klåpare», skriver hon 1924. ${ }^{9}$ Psykologi och socialpsykologi var ju då närmast obruten mark i Sverige och hon fick ägna mycken tid åt att läsa in sig. När hon även fick hand om etikundervisningen bad hon Hesselgren, som redan då hade ett stort internationellt kontaktnät, om tips på moderna socialetiker. Genom henne fick Fogelklou reda på vilken litteratur som användes på London School of Economics i de ämnen hon undervisade i. Glädjande nog fann hon sig »tämligen behärska den engelska litteraturen« och kände sig "rehabiliterad». Men hon ville ha mer material - från Frankrike och Tyskland - för att kunna överblicka sina ämnesområden. ${ }^{10}$

8 Brev från EF till KH, 2/8 1923, Emilia Fogelklous, KHS UB GU, A 1 kartong 53 B.

9 11/5 1924. Brev från EF till Signe Fredholm, personalkonsulent vid tobaksmonopolet i Malmö.

10 Brev från EF till KH, 22/11 24 samt 11/9 25. 
1924 klagade Fogelklou över hur »orimligt med arbete» föreläsningarna kostade henne, men var samtidigt glad över att inte som på folkskoleseminariet behöva traggla om samma kurser, att få "göra nya studier i stället för att repa kursen" (Fogelklou 1979, s 44). Senare beskrev hon sin opraktiska tendens att aldrig upprepa föredrag. Hon "drevs alltid att arbeta vidare genom nya studier« (1954, s 105).

Hur var då undervisningen upplagd? Fogelklou var självfallet präglad av dåtidens psykologiska och socialpsykologiska perspektiv. Instinktteorier hörde till grunderna, men även psykoanalytiska teorier om det omedvetna fanns med. Tydlig var strävan att knyta psykologin till en samhällslära eller, om man så vill, till socialpsykologin. Följande är hennes anteckningar av grundlinjerna till första årets föreläsningar, alltså 1923:

22/10 Etiska och psykologiska lagar bakom det sociala och kulturella livet. Rester $i$ nuet av olika samfundstyper. Samspel kring samhälls- och folkkaraktärer. Personlighetstankens genombrott och dess inverkan $p a ̊$ samhällstyperna

29/10 Det undermedvetnas roll $i$ all modern psykologi. Klarläggandet av det undermedvetnas existens i medico-psykologin (psykoanalys och Nancyskolan) samt inom ny och gammal religionspsykologi.

5/11 Instinkterna och deras omvandling. Komplexer. Familjeinstitutionen - ur biologiska, soc. och psykologiska synpunkter. Känslolivets utveckling.
12/11 Jagkomplexens instinkter - deras omvandling från primitiv självuppehail lelse till personlighetsrespekt och respekt för andra värde. Viljelivet.

19/11 Samhällsinstinkternas komplex (sympati, suggestion, härmning). Betydelse för människors föreställningar, liv, kun skapsoväld. Kunskap om ting. - Samarbetstyper. Riktlinjer mot nya samhällsideal på grundval av psykologiska fakta. ${ }^{11}$

Fokusering på mänskliga relationer, människan i samhället och hur samhällstyper påverkar personligheter bildar en återkommande ram för Fogelklous föreläsningar. 1924 presenterade hon dem i ett brev: „Min första serie på Socialpolitiska institutet gällde socialpsykologi (10 föreläsningar); min nuvarande kurs ("Valda socialetiska och socialpsykologiska problem») gäller arbetets etik i historisk belysning (Zarathustra, klostren, medeltida dombyggen, skråna, Luther). Nästa gång håller jag på med Max Webers Protestantische Ethik und der Geist des Kapitalismus" (Fogelklou 1979, s 44).

Att Fogelklou uppskattade möjligheten att binda ihop psykologi och etik framkom då hon 1934 sökte den Enerothska

11 Anteckningsbok 1923. Anteckningarna gäller föreläsningsserier I 31/5 - 7/6 23, samt II 22/10 23. Grundlinjer till föreläsning i Psykologi. Längst bak i antecknings boken har hon gjort vad hon kallar en resumé över innehållet i kursen, vilken återges här. Texten i originalet är starkt förkortad och jag har fyllt ut förkortningarna där det varit möjligt för större läsbarhet. Ett oläsbart ord är struket. KHS UB GU, Al, kartong 36 
donationsprofessuren, som skulle stödja "läran om sambandet mellan naturlagarna och människans sedliga och fysiska natur" (Bergman Andrews, 1999, s 334, 251). ${ }^{12}$ Ansökan underströk "den teoretiska betydelsen av ett läroämne som kunde kallas 'de mänskliga relationerna' och för vilket intet forum finnes vid svenskt universitet. ${ }^{13}$ I många år hade hon bearbetat dessa frågor "vid populärvetenskapliga föreläsningar i privata kretsar", men endast vid Socialpolitiska institutet hade hon fått "planlägga en föreläsningsserie för psykologi och etik i inbördes relation ${ }^{14}{ }^{14}$

Det är helt klart att Fogelklou uppfattade 1920-talets föreläsningar på Socialpolitiska institutet som det enda tillfälle då hon i en kurs kunde integrera etiska, psykologiska, socialpsykologiska och sociologiska infallsvinklar på mänskliga förhållanden. Mellan 1935 och 1938 förläste hon på nytt för studenter. Denna gång var det föreläsningar vid Stockholms högskola

12 Fogelklou fick dock dra tillbaks denna ansökan. En allvarlig sjukdom hindrade henne från att genomföra den obligatoriska provföreläsningen.

13 Ansökan 1/11 1934. Ansökan innehåller ingående beskrivning av hennes koncept till ämnet för de mänskliga relationerna. Hon var väl medveten om att detta ämne fanns i USA. Ansökan är återgiven nästan i dess helhet i boken Resfärdig, s 106-8. Den utgör ett slags manifest över hennes syn på de sociala, psykologiska och etiska ämnena och hur de enligt hennes uppfattning borde vara sammanfogade. Hennes intresse var inriktat mot att utforska samband mellan olika discipliner.

14 Denna del av ansökan är inte återgiven i Resfärdig. KHS, UB, GU, A 1, kartong 3 A. som var öppna för alla studenter men det var främst studenter från Socialpolitiska institutet som kom. Vi vet med säkerhet att Hesselgren här spelade en viktig roll. Föreläsningarna finansierades $i$ ett donationsbrev undertecknat av bl.a. Hesselgren (Fogelklou 1979, s 111 f). ${ }^{15}$

\section{Psykisk hälsovård}

Då Fogelklou föreläste för studenter på 1930-talet hade hon fått mer direkta erfarenheter av praktiskt socialt arbete. En studieresa till USA hösten 1930 hade givit henne inblickar i wchild guidance clinics"; hon hade följt konferenser med falldiskussioner, läst journaler och samtalat med yrkesföreträdare. Det hela hade gjort ett djupt intryck på henne, och hon insåg att detta var vad hon hade velat syssla med - om det bara hade funnits i Sverige. ${ }^{16}$

Närmast den typen av socialt arbete som Fogelklou kom var den rådgivningsmottagning hon drev några år på 1940talet, först i Kärrgruvan och Fagersta och sedan i Västerås, främst med stöd från Svenska Föreningen för Psykisk Hälsovård. Denna förening bildades 1931 och var ytterligare ett av de sociala projekt som Fogelklou, Hesselgren och Svenson gemensamt var inblandade i för att utveckla det

15 De övriga var Viktor Wigert, chefspsykiater vid karolinska institutet, Olaus Månson, instruktör vid ABF:s Stockholmsavdelning och Anna Sörensen, rektor vid Statens folkskoleseminarium i Stockholm. Enligt Meijling Bäckman 1997, s 250 stod de fyra vännerna personligen för denna donation. Fogelklou var under denna period konvalescent efter en lång sjukperiod.

16 Brev från EF 2/11 1930 till Signe Fredholm. 
sociala arbetet i Sverige. Psykiatern Viktor Wigert var dock den som främst drev på för att bilda föreningen.

Vid föreningsbildningen fick socialministern och medicinalstyrelsens generaldirektör ledande poster i styrelsen. Fogelklou var starkt irriterad över denna form av "allmän dekoration", vilken även fick till följd att Herta Svenson inte kom med i styrelsen. Fogelklou drog sig därför ur styrelsearbetet så snart hon kunde, men Hesselgren kvarstod i många år och blev så småningom föreningens ordförande. Enligt Qvarsell var det vanligt i filantropiska föreningar att knyta nära band med statsmakten, även i en kamporganisation som CSA. I den meningen fanns en kontinuitet mellan Svenska föreningen för psykisk hälsovård och 1800-talets föreningar, men det fanns också likheter i arbetssättet (Qvarsell 1997).

Föreningens uppgift var att på alla tänkbara sätt främja psykisk hälsovård, dels genom att förbättra vården för dem som redan drabbats av psykisk ohälsa, dels genom förebyggande åtgärder. Arbetet skulle bedrivas på flera fronter, för att påverka sjukvård, barnavård, uppfostringsanstalter, brottsbekämpning, samt mer allmänt hälsovården i arbetsliv, hem och skola. Det främsta medlet var upplysning och folkuppfostran, föredrag och skrifter. Särskilt viktigt ansågs det vara att påverka staten och kommunerna. Att upplysa en oupplyst opinion var alltså ett viktigt syfte med föreningen. Det fanns även visioner om att skapa psykiatriska kliniker och rådgivningsbyråer liknande de som fanns $\mathrm{i}$ USA. En övergripande ambition var att få olika yrkesgrupper att samverka med var- andra. Mental hälsovård fick inte bli något som uteslutande sköttes av läkare.

Förutom upplysningsarbete med småskrifter och ett avsevärt antal föreläsningar verkade föreningen för att etablera psykiatriska kliniker och rådgivningsbyråer. Några av 1930-talets byråer för råd i uppfostringsfrågor var länkade till föreningen (SOU 1944:30, s 59-74; Jönsson 1997). Diskussioner fördes även om att föreningen skulle inrätta psykisk rådgivning för vuxna, men det första försöket blev Fogelklous rådgivningsbyrå som öppnade 1946. Den kan också betraktas som en av de första mottagningarna för familjerådgivning $i$ Sverige (Kollind 2002).

\section{Socialt arbete som kvinnligt kall och yrke}

Vi har sett hur Hesselgren, Fogelklou och Svenson på 1910 och 20-talet bidrog till att utveckla socialt arbete som ett yrke, som en avlönad verksamhet. De bidrog även till att utvidga det sociala arbetets gränser till att innefatta även företag. Men de var också aktiva $\mathrm{i}$ ideellt socialt arbete, inte minst genom att vara med och bilda klassöverskridande föreningar och institutioner. De verkade i en brytningstid då nya yrkesmöjligheter öppnades för kvinnor och de var själva med om att skapa sådana. Samtidigt hade filantropin en stark position. Socialt arbete kretsade vid den här tiden mellan att definieras som ett kvinnligt kall respektive som ett yrke.

Många ledande aktörer var tveksamma till att socialt arbete blev ett yrke. Såväl Ebba Pauli som Agda Montelius ansåg att personliga möten mellan hjälpare och 
mottagare måste till för den nödvändiga hjälpen till självhjälp. Utan hjälparens ideella grundåskådning skulle fattigvård förbli en parodi på hjälpverksamhet, menade Pauli. Det krävdes "människor, som i sitt arbete gifva sin personlighet. Människa mot människa i själva arbetet«(Pauli 1905 s 11). Pauli och Montelius fruktade att en professionalisering skulle bädda för byråkrati och formalisering. Samtidigt var Montelius medveten om behovet av utbildning och avlönat arbete (Thörn, 1995). Det fanns en utpräglad ambivalens inför en professionalisering av socialt arbete. Hos båda dessa kvinnor fanns synen på socialt arbete som en kallelse, där viljan att tjäna borde vara den främsta drivkraften, inte försörjningsbehov. För Montelius och Pauli var hjälparbetet nära sammankopplat med kvinnlighet och kvinnans natur. Förmågan att agera personligt, att agera som människa mot människa, ansågs vara en kvinnlig kompetens snarare än en manlig. Kvinnans natur var olik mannens och det var viktigt att värna om just denna olikhet (se Salomonsson 1998, s 31-49).

Detta synsätt var utbrett. Vi finner det hos Meyerson då hon resonerade om lämpliga kvalifikationer för en fabrikssyster. "Allra först kommer det an på personligheten och den är säkert lämpligast, som tar platsen ej som en försörjningsmöjlighet utan som en uppgift. Men nog är en kvinna med bildning och sociala kunskaper att föredraga, ehuru en viss praktisk läggning också är nödvändig." CSA:s kurser var nog bra, men den "drivande kraften" borde vara "medkänsla med och längtan att tjäna arbeterskorna" (Meyerson 1917, s 80). Ett sådant könskomplementärt perspektiv fanns som en självklar utgångspunkt, inte enbart hos filantropiskt aktiva kvinnor, utan även bland många som var engagerade $\mathrm{i}$ dåtidens kvinnorörelse (Manns 1997).

Hur förhöll sig Hesselgren, Fogelklou och Svenson till dessa synsätt? De insåg att arbetslivets förändring och omgestaltningen av samhällets socialpolitik krävde ett socialt arbete på yrkesmässig grund. Men Hesselgren och Fogelklou kombinerade ett särartsperspektiv med ett likställighetstänkande. Kvinnor och män skulle bli formellt likställda i politiken, på arbetsmarknaden, i skyddslagstiftningen, i äktenskapet, men till sin natur var kvinnor och män ändå olika. Detta illustreras av Hesselgrens engagemang i frågan om en husmodersutbildning för alla kvinnor.

Vid samma tid som Hesselgren förmådde Tobaksmonopolet att anställa en fabrikssyster och hon ledde CSA:s kurser i socialt arbete, drev hon i Fredrika Bremerförbundet även frågan om hushållsarbetets professionalisering. Hon fann det angeläget att skapa rationella husmodersutbildningar för både gifta och ogifta kvinnor. I Hesselgrens (och många andra kvinnosakskvinnors) perspektiv skulle kvinnors värde och självständighet öka genom detta. Hushållsarbetet var inte bara ett självklart ansvarsområde för kvinnor, utan också att betrakta som ett kall (Manns 1997, s 195 f).

Fogelklou hade ett tydligare särartstänkande. I en text ägnad rösträttsfrågan vände hon sig mot att kvinnan betraktades som »ett underligt, abstrakt och obestämt väsen" med bestämda egenskaper, alltså "den så kallade Kvinnan». I stället skulle kvinnor precis som män ses som individer med olika unika egenskaper. Samtidigt 
framhöll hon att kvinnans styrka låg $\mathrm{i}$ hennes speciella förmåga till psykologiskt och moraliskt tänkande, alltså att det fanns något gemensamt för alla kvinnor (Fogelklou 1918, s 3f, 9). Vi vet inte hur Svenson såg på dessa frågor, men vi kan ana att hon hade ett likartat perspektiv.

Särartstänkandets realitet för många av denna generations kvinnor behövde inte hindra dem från att ställa krav på likställighet med männen, på yrkesutbildning och rätt till yrkesarbete för kvinnor. Men vissa verksamheter ansågs ändå mer givna för kvinnor. Hit räknade, som vi sett, Meyerson arbetet som personalkonsulent. Det har också framgått att denna gren av det sociala arbetet fick en påtagligt kvinnlig framtoning med hemmet som viktig förebild. Konsulenten skulle ordna med praktiska ting kring trivsel, omsorg, hygien och ge möjlighet till mer personliga möten. Matsalar, barnomsorg, barnkolonier hörde till uppgifterna liksom att skapa möjligheter för bildning och förkovran. Många av dessa element fanns även i hemgårdsrörelsen, som hämtade inspiration från en kristen tankevärld. Att den kristna tron var en viktig drivkraft för många som var verksamma i dåtidens sociala arbete är otvetydigt. Inger Hammar (1998) har hävdat att det funnits en tendens till religionsblindhet $i$ analyser av 1800-talets och det tidiga 1900-talets kvinnorörelser med en tendens att undervärdera de religiösa idéernas betydelse, även ifråga om det filantropiska arbetet. Vad gäller Svenson och Fogelklou är det uppenbart att den kristna tron hade stor betydelse för dem som drivkraft för olika aktiviteter, som de engagerade sig i. Men också hos Hesselgren fanns en religi- öst grundad drivkraft, om än mindre öppet uttalad. Losman skriver att hennes gudstro var av den "nyktra, plikttrogna, verksamhetslystna sorten", utan inslag av svärmeri. En kristens plikt var för henne watt hjälpa sina medmänniskor", och det sociala arbetet gav denna möjlighet (Losman 1980, s $67,69)$.

Vad hände då med personalkonsulenterna? Enligt Margareta Damm dominerade kvinnor det arbete som personalkonsulenter bedrev fram till 1940-talet, och de var främst verksamma i kvinnodominerade industrier. Men då verkstadsindustrin började anställa personalkonsulenter försökte man rekrytera män. När sedan på 1950-talet inflytandet för personaladministrativa synsätt ökade, aktualiserades frågan om gränsdragningen mellan administration och personalvård. På 1960-talet uppkom nya motsättningar mellan personalvårdande målsättningar och företagsekonomiska intressen och efterhand försköts tyngdpunkten i riktning mot administrativa, tekniskt-rationella perspektiv. Därmed försvann alltmer av det slags konsulentarbete som SAIA-kvinnorna skapade (Damm 1993, s 44 f, 54 f).

\section{Avslutande reflektioner}

Jag vill avslutningsvis beröra några frågor som ansluter till det sociala arbetets historia. I dess idéhistoria är en vanlig förebild det settlement Jane Addams skapade på Hull House i Chicago vid det förra sekelskiftet. I en jämförelse av socialt arbete $i$ USA och Sverige konstaterar Pettersson att den svenska utvecklingen snart kom att domineras av ämbetsmän, lagstiftning och 
tjänstemannarollen. I Sverige fanns ingen som likt Mary Richmond eller Jane Addams arbetade praktiskt och samtidigt teoretiskt analyserade frågor som berörde det sociala arbetets metodik (Pettersson 2001, s 57f).

Det finns naturligtvis stora skillnader mellan kvinnorna på Hull House och de som i Sverige drev fram stugrörelsen, hemgårdarna och personalkonsulenterna. Verksamheten i USA hade en helt annan omfattning och betydelse. Men vi kan se paralleller på en rad punkter: de pådrivande kvinnornas borgerliga bakgrund, deras strävan att ge människor från olika samhällsklasser mötesplatser, viljan att lära av arbetare och arbeterskor i reformarbetet, arbetet kring arbetarskyddsfrågor, betoningen av praktiskt arbete och folkbildning, kristen religiositet som drivkraft, bejakandet av ett demokratiskt samhälle. De aktiva i Sverige har lämnat mycket lite dokumentation efter sig, praktiskt taget inga skrifter alls om det sociala arbetets metoder. I Sverige saknades också en intellektuell miljö av det slag kvinnorna på Hull House kunde skapa i samverkan med sociologer och pedagoger vid Chicagouniversitetet, främst professorerna George H. Mead och John Dewey.

Jag menar att det finns flera berörings- punkter mellan Addams, Mead, Dewey och Fogelklou. Pedagogiskt nytänkande, betoning på mänskliga relationer och synen på gemenskap som primär för allt mänskligt liv samt intresset för att skapa nya typer av institutioner som gynnar framväxten av ett demokratiskt samhälle är några exempel på sådana likheter. Men Fogelklou begränsades av att inte ha en yrkesmässig bas för att utveckla sina tankegångar. Därför var föreläsningarna vid Socialpolitiska institutet så viktiga. De var det närmaste hon kom en plattform för att systematiskt kunna reflektera kring frågor om ramar och villkor för tidens sociala arbetsformer.

Makarna Swedner drar i en studie om Hull House paralleller mellan Jane Addams och Ellen Key eller Elin Wägner (Swedner och Swedner 1995, s 127). Jag menar att Emilia Fogelklou, Herta Svenson, Kerstin Hesselgren och de övriga kvinnor som samverkade i nätverk på 1910-talet och framåt utgör en närmare svensk parallell. De utgör tidiga exempel på praktiskt samhällsarbete. Inte minst viktigt var deras initiativ när det gällde att föra över socialt arbete från ideella välgörenhetsinsatser och lägga grunderna för ett professionellt yrkesarbete.

\section{Referenser:}

Bergman Andrews, Malin (199) Emilia Fogelklou, människan och gärningen - en biografi. Skellefteå: Artos bokförlag

Beskow, Nathanael (1910) "Den stora lockouten och den stora strejken 1909", Social Tidskrift nr 5,6 1910 .

Boalt, Gunnar \& Bergryd, Ulla (1974) Central- förbundet $i$ socialt arbete. Ett kapitel svensk socialpolitik. Stockholm: Centralförbundet för socialt arbete.

Damm, Margareta (1993) Personalarbete - yrke eller passion. Göteborg: Margareta Damm och BAS ek för.

Eskilsson, Lena (1991) Drömmen om kamratsam- 
hället. Kvinnliga medborgarskolan på Fogelstad. Stockholm: Carlssons

Fjällbäck Holmgren, Karin (1925) "Social utbildning", i von Koch, G. H., red,: Social Handbok. Översikt av offentligt och enskilt samhällsarbete $i$ Sverige. Stockholm: Lars Hökerbergs Bokförlag, s 423-429

Fjällbäck Holmgren, Karin (1928) „Historik« i Centralförbundet för Socialt Arbete 1903 - 1928.

Minnesskrift, Stockholm, s 13- 43

Fogelklou, Emilia (1918) Icke i trötthetens tecken. Rösträttsbrevet för dagen III. Landsföreningen för kvinnans politiska rösträtt.

Fogelklou, Emilia (1950) Barhuvad, Stockholm: Bonniers

Fogelklou, Emilia (1954) Resfärdig, Stockholm: Bonniers

Fogelklou, Emilia (1979) Brev till vännerna. Urval och inledning av Gunnel Vallquist. Stockholm: Natur och Kultur

Gustafsson, Ingemar (1989) „Kerstin Hesselgren - den charmerande socialreformatorn", i Ifrain Gästrikland 1987. Gävle: Gästriklands kulturhistoriska förenings meddelanden, s 5-46

Hammar, Inger (1998) "Några reflexioner kring 'religionsblind' kvinnoforskning", i Historisk tidskrift, nr 1

Hamrin-Thorell, Ruth, Gärde Widemar, Ingrid, Myrdal, Alva \& Bergman, Malin (1968) Boken om Kerstin Hesselgren. En vänstudie. Stockholm: P. A. Norstedts \& Söners Förlag

Hesselgren, Kerstin (1905) »Tändsticksindustrien i Tidaholm. Några studier och reflexioner. Del I."Social Tidskrift, 12

Hesselgren: (1904) "En livsfråga för vårt folk», Social Tidskrift, 3

Isaksson, Ulla \& Linder, Hjalmar (1980) Elin

Wägner. Dotter av moder jord 1922-1949. Stockholm: Bonniers

Jordansson, Birgitta (1992) »Hur filantropen blev en kvinna. Fattigvård och välgörenhet under 1800 talet». Historisk tidskrift nr 4, s 468-487

Jönsson, Ulf (1997) Bråkiga, lösaktiga och nagelbitande barn: Om barn och barnproblem vid en rådgivningsbyrå i Stockholm 1933-1950. Linköping: Linköping Studies in Arts and Science

Kollind, Anna-Karin (2002) Äktenskap, konflikter och rådgivning. Från medling till samtalsterapi. Stockholm: Carlssons

Lindblad, Linnéa (2002) „Kerstin Hesselgren nästan alltid föst", i Holmberg, H., red.: Liberala pionjärer. Uppsla: Uppsala Publishing House $\mathrm{AB}$

Losman, Beata (1980) Kamp för ett nytt kvinnoliv. Ellen Keys ideer och deras betydelse för sekel skiftets unga kvinnor, Stockholm: Liber Förlag

Meijling Bäckman, Ingrid (1997) Den resfärdiga. Studier i Emilia Fogelklous självbiografi. Stockholm: Brutus Östlings bokförlag Symposion

Manns, Ulla (1997) Den sanna frigörelsen. Fred rika-Bremer-förbundet 1884-1921. Stockholm/ Stehag: Brutus Östlings Bokförlag symposion

Meyerson, Gerda (1917) Arbeterskornas värld - studier och erfarenheter. Stockholm: Hugo Gebers förlag

Norlander, Kerstin (1995): „Den kollektivistiska husmoderligheten. Södra KFUK och fabriksarbeterskorna i Stockholm 1887 - 1930«, i Taussi Sjöberg, M., Vammen, T. red,: På tröskeln till välfärden. Välgörenhetsformer och arenor $i$ Norden 1800-1930. Stockholm: Carlssons

Olson, Hans-Erik (1982) Från hemgård till ungdomsgård. En studie i den svenska hemgårdsrörelsens historia. Stockholm: RSFH: s förlag

Pauli, Ebba (1905) „Det personliga i fattigvårdsarbetet", i Fattigvård och folkförsäkring. Stockholm: Skriftserie utgiven av CSA, nr 4

Pettersson, Ulla (2001) Socialt arbete, politik och professionalisering. Den historiska utvecklingen $i$ USA och Sverige. Stockholm: Natur och kultur Qvarsell, Roger (1993)»Välgörenhet, filantropi och frivilligt socialt arbete - en historisk översikt", i Frivilligt socialt arbete. Kartläggning och kun skapsöversikt. Statens offentliga utredningar, SOU 1993:82, Stockholm, s 217-241

Qvarsell, Roger (1997) „Mentalhygien och psykisk hälsovård", i Eriksson, B-E. \& Qvarsell, R., red.: Hur skall själen läkas? Den psykiatriska vårdens förändringar. Stockholm: Natur och Kultur, s 127-154

Sjöholm, Öyvind (1972) Samvetets politik. Natanael Beskow och hans omvärld intill 1921. Verbum

SOU 1944:30 (1944) Ungdomsvårdskommit

Anna-Karin Kollind: Kvinnor och socialt arbete - vid övergången från filantropi till profession 
téns betänkande I, med utredning och förslag angående psykisk barna- och ungdomsvaird. Stockholm

Sundin, Sven (1986) Södergården. Sveriges andra hemgård, 1916-1986. Stockholm: RSFH:s Förlag

Svenson, Herta (1916) i Södertunabladet

Swedner, Gunnel \& Swedner, Harald (1995)

Pionjärer $i$ socialt arbete. Om Jane Addams och hemgården Hull House. Stockholm: Liber utbildning

Thörn, Kerstin (1995) „Föreningen för Välgörenhetens Ordnande och bostadsfrågan" i Taussi Sjöberg, M., Vammen, T. red,: På tröskeln till välfärden. Välgörenhetsformer och arenor $i$ Norden 1800-1930. Stockholm: Carlssons

Wirén, Agnes (1980) G. H. von Koch. Banbrytare $i$ svensk socialvård. Stockholm: Rabén \& Sjögren

\section{Summary}

\section{Women and social work - in the transition from philanthropy to a profession}

In Sweden, the professionalization of social work was initiated at the end of the nineteenth century and the beginning of the twentieth. This process was diverse and occurred in many ways. The article describes some of the activities in this history and takes as its point of departure three women who contributed to the process. These women - Kerstin Hesselgren, Emilia Fogelklou and Herta Svenson - constituted a social network, i.e. they knew each other well and acted jointly to promote what they believed in.

Svenson and Fogelklou were some of numerous female Christian activists who engaged in projects with the aim of bringing the working class and the educated class closer to each other. One of these projects involved the creation of settlements in Sweden, the other one enabled recreation for working women. These projects started in 1911 and 1912. Hesselgren, who then became a factory women inspector, wanted to come in closer touch with workingwomen and took part in these projects. She soon managed to get Svenson employed as a factory social secretary, which meant that social work came to include the factory world as well.

Hesselgren was active in promoting one of the first professional courses in social work, and, when this was institutionalised in 1921, Fogelklou lectured in psychology and ethics for almost a decade. A survey of the content of these courses is given.

It is argued that these women contributed to the professionalization of social work, although the boundaries between the voluntary and professional social projects in which they engaged were fluid. It is also argued that there are some parallels between these women's joint activities and those that occurred at Hull House in the USA. 